\title{
Skinnebehandling mot søvnapné
}

\author{
Apnéskinner er et godt dokumentert og nødvendig behandlingsalternativ for obstruktivt søvnapnésyndrom. \\ Ved Senter for søvnmedisin. Haukeland universitetssykehus, er det etablert en klinikk med tannlegespesia- \\ lister som en del av det tverrdisiplinære teamet.
}

Søvnapné innebærer gjentatte pustestopp under søvn, som oftest skyldes obstruksjon i de øvre luftveiene, og som da betegnes obstruktiv søvnapné. I en undersøkelse fra Norge angis det at 16\% mellom 30-65 år har denne tilstanden (1). Snorking er et vanlig symptom på obstruktiv søvnapné, men ikke alle snorkere har sykdommen. Snorking er vanlig, med en forekomst i Norge på $20 \%$ hos voksne kvinner og $33 \%$ hos menn (1).

Når snorking forekommer uten pustestopp, snakker vi om sosial snorking. Personer med søvnapné derimot, rapporterer ofte uttalte dagtidssymptomer. Da betegnes tilstanden som obstruktiv søvnapnésyndrom. Snorking alene uten pustestopp gir generelt lite symptomer, men vil kunne medføre redusert søvnkvalitet hos både partner og den som snorker.

\section{Konsekvenser}

Obstruktiv søvnapnésyndrom er foruten pustestopp og dagtretthet også forbundet med andre symptomer og komorbiditeter, som nattlige oppvåkninger, gisping etter luft, redusert konsentrasjonsevne, nedsatt reaksjonstid, hypertensjon og andre kardiovaskulære sykdommer, i tillegg til metabolske tilstander, astma og depresjon. Det er rapportert forkortet levealder i denne pasientgruppen (2).

De medisinske og sosiale konsekvensene kan være betydelige, og det er derfor viktig med tidlig diagnostikk. For å stille diagnosen må man i tillegg til subjektive mål, basert på en grundig anamnese, også utføre objektive målinger. Polysomnografi er «gullstandard», men en ressurskrevende prosedyre. Ved høy pretest sannsynlighet for obstruktiv søvnapnésyndrom er polygrafi en godt validert metode (3), og alvorlighetsgraden vurderes etter antall pustestopp per time - apné-hypopné-indeks (AHI): mild: 5-14, moderat: 15-29, alvorlig: $\geq 30$. I tillegg vurderes graden av søv- nighet på dagtid og oksygenmetning gjennom natten.

\section{Skinne et alternativ}

I spesialisthelsetjenesten har hovedsakelig tre behandlingsformer for søvnapné vært i bruk. Det er bløtvevskirurgi i svelg/gane, applikasjon av positivt luftveistrykk via ansiktsmaske (CPAP) og apnéskinne.

Kirurgi har tidligere vært den vanligste behandlingsformen av snorking og mild/ moderat obstruktiv søvnapné i spesialisthelsetjenesten (4). I rapporten om behandlingspraksis i de nordiske land i 2007 ser vi at Norge har ligget langt under Sverige når det gjelder behandling med skinnetilpasning og langt over Sverige når det gjelder bruk av kirurgi (3). Langtidsoppfølginger av kirurgisk behandling har imidlertid vist lite tilfredsstillende resultater $(3,4)$, og er nå forbeholdt barn med tonsillehypertrofi og en mindre kategori voksne etter grundig utredning av obstruksjonsnivå.

I dag regnes CPAP-behandling som «gullstandarden» ved obstruktiv søvnapné (3). En relativt stor andel pasienter sliter imidlertid med bruken (5), og ved dårlig etterlevelse kan apnéskinnebehandling være et godt alternativ. Ved mild/moderat obstruktivt søvnapnésyndrom viser apnéskinner en effekt på subjektive og objektive parametere som er på linje med CPAP (6, 7). Den blodtrykksreduserende effekten er sammenliknbar med CPAP-behandling (8), og kardiovaskulær dødelighet er lik ved begge behandlingsmetodene (9). Det spekuleres i om helseeffekten av apnéskinner versus CPAP er sammenliknbar fordi apnéskinnebehandling har en bedre langsiktig etterlevelse. Etter ett år bruker fortsatt tre av fire pasienter apnéskinnen, mens omkring halvparten fortsatt bruker CPAP (5). Vi bør imidlertid poengtere at etterlevelse med skinne, til forskjell fra CPAP, oftest er selvrapportert, hvilket kan medføre noe feilinformasjon. Vår kliniske erfaring tyder på at

Tabell 1 Indikasjoner for apnéskinne, etter anbefalinger fra internasjonale søvnforeninger

$\begin{array}{ll}\text { Indikasjoner } & \text { Merknad } \\ \text { Snorking } & \begin{array}{l}\text { Effektiv, men ingen sikre data foreligger på helseeffekten av behandling } \\ \text { mot snorking }\end{array} \\ \begin{array}{l}\text { Mild til moderat } \\ \text { søvnapné }\end{array} & \begin{array}{l}\text { «Non-compliant» til CPAP og andre alternative behandlinger som } \\ \text { vektreduksjon/posisjonsterapi } \\ \text { Ønsker skinne fremfor CPAP }\end{array} \\ \text { Alvorlig søvnapné } & \begin{array}{l}\text { CPAP-behandling skal ha vært prøvd fordi effekten av denne behandlingen } \\ \text { antas å være bedre }\end{array}\end{array}$

skinnen har god effekt både på subjektive og objektive søvnparametere, spesielt ved mild/moderat søvnapné, men også noen ganger ved alvorlig, som støttes av nyere studier $(7,10)$.

Skinnebehandlingsindikasjonene er blitt utvidet de seneste årene og omfatter foruten snorking også flere undergrupper av obstruktiv søvnapné. Internasjonale søvnforeninger, i USA, Australia og Canada, har gitt anbefalinger for bruk av apnéskinne, sammenfattet i tabell 1. Det finnes ikke tilsvarende norske retningslinjer.

\section{Fra eksternt samarbeid til full integrering}

Apnéskinnebehandling er blitt en mer vanlig behandlingsform i Norge. Vårt inntrykk er likevel at det er betydelige forskjeller i praksis mellom de nordiske land, noe som kan skyldes ulik kunnskap om behandlingsformen innenfor odontologi og medisin. Forskjeller i refusjonsregler kan også ha betydning for behandlingspraksis. I Norge faller apnéskinner ved søvnapné inn under kategorien behandlingshjelpemidler med dekningsansvar i helseforetakene fra år 2008, ifølge spesialisthelsetjenestelovens $\S 2-1 \mathrm{a}$. I Sverige har apnéskinnebehandling vært dekket via Det statliga tandvårdsstödet/ tandvårdsförordningen som trådte $\mathrm{i}$ kraft i 1999 .

I Bergen har tannleger med spesialkompetanse i flere år behandlet søvnapnépasienter med apnéskinne i samarbeid med Haukeland universitetssykehus. Med dette som bakgrunn er en kollaborasjon også blitt utviklet mellom Lungeavdelingen ved Haukeland universitetssykehus og odontologimiljøet ved Universitetet i Bergen. Etter at Senter for søvnmedisin ble en realitet i mars 2011, har Helse Bergen, gjennom Lungeavdelingen som administrativt ansvarlig, utviklet dette til et tverrdisiplinært senter som innbefatter leger, sykepleiere og merkantilt personell fra Øre-nese-hals-avdelingen, Lungeavdelingen, Nevrologisk avdeling, Nevrofysiologisk avdeling og Psykiatrisk avdeling, og siste året også tannleger. Et tannlegekontor med nødvendig utstyr sto klart 1. februar 2013. Etter ett års prosjektdrift er dette fra 2014 blitt et permanent behandlingstilbud med fast ansatte overtannleger som en del av behandlingsteamet. En fast stilling deles mellom tre tannleger med forskningsbakgrunn, og videre forskning vil kunne øke kunnskapsgrunnlaget for apnéskinnebehandling.

På senteret tilpasser tannlegene apnéskin- 


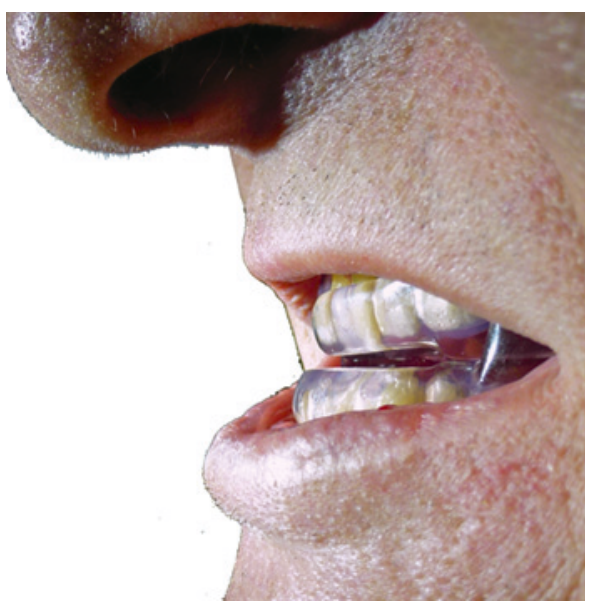

En av de vanligste type skinner som anvendes ved behandling av søvnapné. Foto: Privat

ner til pasienter som har prøvd ut CPAP i minst tre måneder og som viser dårlig etterlevelse, definert som gjennomsnittlig bruk $<5$ timer per natt. Tannlegen tar avtrykk, kjeveregistrering og tilvirker justerbare apnéskinner tilpasset hver pasients kjeve. Når pasient og tannlege er fornøyd med skinnens funksjon, utføres ny polygrafi som objektivt mål på skinnens effekt. Posisjonen justeres for å oppnå best mulig effekt. Pasientens subjektive oppfatning av skinnen blir registrert ved spørreskjema og samtale. Dersom tilfredsstillende objektive og subjektive resultat ikke oppnås etter flere justeringer, kan bytte av skinne eller annen type behandling være aktuelt. En kvalitetssikring/ oppfølging av pasienter som siden 2007 har fått apnéskinne for moderat og alvorlig søvnapné pågår.

\section{Veien videre?}

Vi tror at volumet av pasienter med obstruktiv søvnapné som behandles med skinner vil øke i fremtiden. I mars 2014 står 52 pasienter på venteliste for apnéskinnebehandling ved Haukeland universitetssykehus. Dokumentasjonen er god for skinnebehandling ved mild/moderat søvnapne, men ved alvorlig grad behøves fortsatt mye forskning på behandlingseffekt. Tverrdisiplinært samarbeid er viktig ved diagnostikk, behandling og oppfølging. Skinnebehandling dekkes av foretakene, men helseforetak i Norge velger nå forskjellige modeller for organisering - de fleste med anbud til private aktører. Utfordringen er å sikre et faglig godt samarbeid og oppfølging av denne pasientgruppen.

Vi anbefaler vår modell av følgende grunner: Behandling med apnéskinner utføres av erfarne tannleger med spesialkompetanse i odontologisk søvnmedisin, og standardiserte pasientforløp for diagnostikk og kontrollopplegg etableres og kvalitetssikres enklere $\mathrm{i}$ virksomheter med alle aktører i samme enhet. Videre unngås logistikkutfordringer i forhold til henvisninger og rehenvisninger og avtaleverk og fakturering mellom aktører i og utenfor sykehus, og all dokumentasjon samles på ett sted. Kompetanseheving for tannleger og andre helsearbeidere $\mathrm{i}$ teamet forenkles på grunn av fysisk samlokalisasjon samtidig som mulighetene for forskning økes.

\section{Anders Johansson \\ anders.johansson@iko.uib.no \\ Kjersti Gjerde \\ Sverre Lehmann \\ Bjørn Bjorvatn \\ Kahtan Al-azawy \\ Shashi Gulati \\ Morten E. Berge}

Anders Johansson (f. 1957) er overtannlege, Senter for søvnmedisin, Lungeavdelingen, Haukeland universitetssykehus. Han er også professor ved Institutt for klinisk odontologi, Universitetet i Bergen og spesialist i oral protetikk/bittfysiologi.

Forfatter har fylt ut ICMJE-skjemaet og oppgir ingen oppgitte interessekonflikter.

Kjersti Gjerde (f. 1956) er overtannlege, Senter for søvnmedisin, Lungeavdelingen, Haukeland universitetssykehus.

Forfatter har fylt ut ICMJE-skjemaet og oppgir ingen oppgitte interessekonflikter.

Sverre Lehmann (f. 1966) er spesialist i indremedisin og i lungesykdommer, med spesialkompetanse i obstruktive lungesykdommer og søvnrelaterte respirasjonsforstyrrelser. Han er også seksjonsoverlege ved Lungeavdelingen ved Haukeland universitetssykehus og førsteamanuensis ved Universitetet i Bergen. Han er medlem av Nasjonal kompetansetjeneste for søvnsykdommer.

Forfatter har fylt ut ICMJE-skjemaet og oppgir ingen oppgitte interessekonflikter.

Bjørn Bjorvatn (f. 1963) er søvnspesialist og professor ved Universitetet i Bergen. Han er leder av Nasjonal kompetansetjeneste for søvnsykdommer og Senter for søvnmedisin ved Haukeland universitetssykehus og spesialist i allmennmedisin.

Forfatter har fylt ut ICMJE-skjemaet og oppgir ingen oppgitte interessekonflikter.

Kahtan Al-azawy (f. 1964) er spesialist i indremedisin og i lungesykdommer med spesialkom petanse i respirasjonssvikt/søvnrelaterte sykdommer. Han er avdelingsdirektør ved Lungeavdelingen, Haukeland universitetssykehus. Forfatter har fylt ut ICMJE-skjemaet og oppgir ingen oppgitte interessekonflikter.
Shashi Gulati (f. 1956) er spesialist i øre-nesehals-sykdommer og seksjonsoverlege på Ørenese-hals-avdelingen, Haukeland universitetssykehus. Medlem av Nasjonal kompetansetjeneste for søvnsykdommer

Forfatter har fylt ut ICMJE-skjemaet og oppgir ingen oppgitte interessekonflikter.

Morten E. Berge (f. 1955) er overtannlege, Senter for søvnmedisin, Lungeavdelingen, Haukeland universitetssykehus. Han er også professor ved Institutt for klinisk odontologi, Universitetet i Bergen og spesialist i oral protetikk.

Forfatter har fylt ut ICMJE-skjemaet og oppgir ingen oppgitte interessekonflikter.

Litteratur

1. Hrubos-Strøm H, Randby A, Namtvedt SK et al. A Norwegian population-based study on the risk and prevalence of obstructive sleep apnea. The Akershus Sleep Apnea Project (ASAP). J Sleep Res 2011; 20: 162-70

2. Gami AS, Olson EJ, Shen WK et al. Obstructive sleep apnea and the risk of sudden cardiac death: a longitudinal study of 10,701 adults. J Am Coll Cardiol 2013; 62: 610-6

3. Franklin K, Rehnqvist N, Axelsson S. Obstructive sleep apnoea syndrome. Report of a joint Nordic project. A systematic review. Stockholm: Statens beredning för medicinsk utvärdering, 2007.

4. Lehmann S, Grebstad J, Fondenes O et al. Behandling av obstruktiv søvnapné. Tidsskr Nor Lægeforen 2005; 125: 199.

5. Chan AS, Cistulli PA. Oral appliance treatment of obstructive sleep apnea: an update. Curr Opin Pulm Med 2009; 15: 591-6.

6. Aarab G, Lobbezoo F. Heymans MW et al. Longterm follow-up of a randomized controlled trial of oral appliance therapy in obstructive sleep apnea. Respiration 2011; 82: 162-8.

7. Doff MH, Hoekema A. Wijkstra PJ et al. Oral appliance versus continuous positive airway pressure in obstructive sleep apnea syndrome: a 2-year follow-up. Sleep 2013; 36: 1289-96.

8. Iftikhar IH, Hays ER, Iverson MA et al. Effect of oral appliances on blood pressure in obstructive sleep apnea: a systematic review and meta-analysis. J Clin Sleep Med 2013; 9: 165-74.

9. Anandam A, Patil M, Akinnusi M et al. Cardiovascular mortality in obstructive sleep apnoea treated with continuous positive airway pressure or oral appliance: an observational study. Respirology 2013; 18: 1184-90.

10. White DP, Shafazand S. Mandibular advancement device vs. CPAP in the treatment of obstructive sleep apnea: are they equally effective in short term health outcomes? J Clin Sleep Med 2013; 9: $971-2$.

Mottatt 17.3. 2014, første revisjon innsendt 7.4. 2014, godkjent 10.4.2014. Redaktør: Kari Tveito.

Publisert først på nett.

Engelsk oversettelse på www.tidsskriftet.no 